LEITURA - ESPAÇOS HÍBRIDOS: n. 28, n.29, p.281-304.

\title{
DO TEMPO DA HISTÓRIA AO ENTRETEMPO DA FICÇÃO: A IRONIA EM TERRA PAPAGALLI
}

\section{Rejane Cristina Rocha ${ }^{(*)}$}

Resumo: O presente artigo busca investigar as formas como, por meio do processo irônico, uma obra da literatura brasileira contemporânea revê criticamente o passado histórico e aponta as mazelas do presente, mirando sempre um "entretempo" no qual a nação brasileira se constituiu.

Palavras-chave: Ficção; História; ironia

Ler é como uma aposta. Apostamos que seremos fiéis às sugestões de uma voz que não diz explicitamente o que está sugerindo (Umberto Eco).

A epígrafe que escolhemos para a introdução deste trabalho fornece pistas a respeito dos enredamentos de que o leitor é vítima quando diante de um texto literário. Doce vitimação, porém, já que desse processo o leitor não sai lesado, muito pelo contrário.

Umberto Eco (1994, p.118), nesse fragmento escolhido como epígrafe, aproxima o processo de leitura ao contrato de um jogo de azar, em que as apostas são feitas às cegas e cujo resultado é imprevisível. Interessa notar que, a despeito dos riscos, a aposta é feita por livre e espontânea vontade pelo apostador-leitor. Na verdade, há o desejo de enredar-se, de deixar-se levar pela tal voz que, exatamente por não explicitar suas sugestões, exerce o fascínio do canto da sereia.

A leitura que ora propomos da obra Terra Papagalli ' (Torero \& Pimenta, 1997) tenta compor os fios dessa rede que captura os incautos apostadores do jogo da leitura. É no encalço dessa voz, que diz menos do que o necessário a fim de que o dito signifique mais, que cedemos, inúmeras vezes, à dissimulação irônica, traço marcante da obra.

(") Mestre e doutoranda em Estudos Literários pela Unesp, campus de Araraquara.

'. Todas as citações dessa obra, feitas no corpo do texto, referem-se a essa edição. 
Para compreender a dissimulação em uma obra em que o projeto de falar de um outro tempo lança-nos, invariavelmente, em direção ao tempo presente e em que a construção ficcional esbarra nos dados historiográficos e empurra-nos em direção ao que é extratextual, é necessário observar como o passado histórico, por meio de seus relatos, contribui para a construção da obra literária, de que maneira e em que medida esses relatos são aproveitados e o que faz com que esses recortes históricos ganhem vida ficcional e estética. Além disso, é importante observar, ainda, de que forma a História, que quando incorporada pela ficção traz à tona o já-dito, o já-conhecido, altera o pacto ficcional, o modo como o leitor olha para essa ficção e a interpreta.

\section{A ironia em Terra Papagalli}

A apreensão do enunciado irônico requer do leitor, em primeiro lugar, disposição para "ler" dois ou mais significados simultaneamente sem desprezar nenhum, ao mesmo tempo que apreende um terceiro, resultante do atrito desses dois, o qual chamamos, efetivamente, de significado irônico. No título da obra em questão, Terra Papagalli, essa convergência de significados relacionase tanto com a sua expressão em língua latina quanto com a sua transposição para o português.

Sabe-se que o conhecimento do latim foi, durante muito tempo, sinal conotador de cultura, já que os poucos letrados religiosos e alguns representantes da nobreza - tinham a educaçĩo humanística pautada nos textos latinos. Com o passar do tempo e com a popularização da educação, o latim acabou tornando-se ornamento discursivo, ou seja, passou a ser instrumento para representar uma certa erudição, mesmo que forjada.

O título em latim da carta biográfica escrita por Cosme Fernandes contrasta com o teor da própria carta e, mesmo, com o feitio do escritor, cujo conhecimento da língua resumia-se às colas ocultadas no capuz, à época em que estava no seminário (Torero \& Pimenta, 1997, p. 12). Esse contraste evidencia o desejo de Cosme de atribuir importância aos seus escritos.

No entanto, a utilização dessa língua coloca em funcionamento um outro significado, além daquele ligado à ostentação de um certo lastro cultural. Podemos, de acordo com o que afirma 
Beth Brait (1996, p.107-8), encarar a expressão do título em latim como uma "forma de recuperação do já-dito" com objetivo irônico. De acordo com a autora, tais formas

não assumem ... a função de erudição, no sentido de
invocação de autoridade e muito menos de simples
ornamento. Ao contrário, são formas de contestação da
autoridade, de subversão de valores estabelecidos ...
Assim sendo, o processo de participação na constituição
do interdiscurso irônico pode reverter não apenas figuras
de autoridade, mas relativizar valores estabelecidos.

Outro enunciado latino aparece na obra para intitular o bestiário e, mais uma vez, o intuito do narrador parece ser o de valorizar, agora cientificamente, um discurso duvidoso, pelo menos no sentido científico, ao mesmo tempo em que desvaloriza outros discursos que se utilizaram do mesmo expediente de tentar conferir legitimidade a um texto pela utilização da língua latina no seu título. É necessário observar," sob risco de não colocar a ironia em funcionamento, que ao utilizar esse expediente - o de promover uma valorização, por vezes forçada, do discurso pelo emprego do latim promove-se uma avaliação crítica desse tipo de expediente e dos discursos que dele se utilizaram.

Todos esses significados irônicos, que são colocados em funcionamento pelo uso da língua latina no título, aliam-se ao tom satírico da obra quando se percebe que os enunciados em questão (Terra Papagalli e Liber monstrorum de diversis generibus) são escritos, na verdade, numa espécie de "falso latim". No caso, a expressão "terra dos papagaios" equivaleria à expressão latina "terra pappagallorum”, já que o caso genitivo plural é construído por meio da desinência "-orum" (a desinência "-i" acusa a construção do genitivo singular: terra do papagaio). O que ocorre na expressão Liber monstrorum de diversis generibus, que poderia ser "traduzida" como livro de monstros de diversos gêneros, é um pouco diferente: as desinências são aplicadas corretamente, no entanto, estão associadas a vocábulos não-latinos e organizam-se em uma estrutura frasal típica do português, resultando em uma nova língua, híbrida, em que Camões e Virgílio se encontrariam.

O personagem-narrador propagandeia seus falsos dotes intelectuais por meio de um expediente que, por sua vez, também é 
forjado. A utilização das conhecidas terminações latinas, que caracterizam as declinações típicas da língua, cumprem o papel de enganar os incautos.

A transposição do título para o português coloca em pauta um outro tipo de reflexão por parte do leitor. A primeira pergunta a fazer é: por que Terra dos Papagaios ${ }^{2}$ ? Se a abundância, verificada pelo narrador, dessas aves na terra recém-aportada pode legitimar o título, a abundância de outros animais, insetos, plantas, também poderia. O Novo dicionário Aurélio da língua portuguesa (FERREIRA, 1986, p.1259) traz, no verbete "papagaio", além das esperadas definições zoológicas, o seguinte: "pessoa que repete o que ouviu ou leu sem entender o sentido”. Esse sentido consignado pelo dicionário colocará em funcionamento uma ironia que, mais uma vez, exigirá do leitor a disposição de apreender diversos significados, estendidos, também, para além da obra.

O vocábulo papagaio passará a evocar, então, sentidos relacionados à nossa história de colonização, dependentes e submissos economicamente e legalmente da Coroa Portuguesa durante três séculos. No entanto, esse sentido não fica restrito ao período colonial. A reiterada estratégia da obra de oscilar entre o dito sobre o passado e o dissimulado sobre o presente, autoriza que o leitor estenda o significado "pessoas que repetem tudo sem pensar ou entender" à nossa situação atual, em que importamos dos países desenvolvidos, sobretudo dos Estados Unidos, o que vemos na TV e no cinema, o que ouvimos no rádio, as roupas que vestimos e, até mesmo, muitas das palavras que utilizamos.

Observe-se que o funcionamento do significado irônico proposto acima depende não somente da transposição do título latino

\footnotetext{
A despeito de não termos encontrado referências claras a respeito, parece
que o designativo "Terra dos Papagaios" já era empregado com sentido pejorativo à época das expedições que se sucederam à de Cabral. (Ver, a esse respeito, O descobrimento do Brasil, de Capistrano de Abreu [1976]). Há, também, indícios de um certo mapa em que as terras brasileiras figuravam com este nome. Conforme Azevedo, no artigo "Terra Pappagallorum", publicado no jornal Folha de S. Paulo em 26 de março do 2001, "um mapa de 1500, premonitoriamente, já identificava o Brasil como a 'Terra Pappagallorum' ('Brasilia sive Terra Pappagallorum' e 'Terra Pappagallorum: potrebe chiamarse Pindorama')".
} 
para o português, mas da apreensão, por parte do leitor, dos contextos ${ }^{3}$ que envolvem esse título e o seu equivalente em Português.

\section{Mundo, textos e intertextos: os contextos da ironia}

De acordo com Linda Hutcheon (2000, p.206), a interpretação da ironia pressupõe a reflexão acerca de três tipos de contextos: o circunstancial, o textual e o intertextual.

O contexto circunstancial envolve o que Jakobson ${ }^{4}$ chamou de contextos social e físico. Assim, o título, em português, Terra dos Papagaios, ao nomear uma obra lançada às vésperas das comemorações dos 500 anos da "descoberta" do Brasil, quando os debates a respeito da formação de nossa identidade nacional estavam acirrados, cria uma ironia que coloca em pauta - e em dúvida - a validade das comemorações e dos debates. Afinal, se se trata de uma terra dos papagaios, no sentido irônico que acima expusemos, talvez nem tenhamos, ainda, identidade.

O contexto textual, que compreende "o ambiente textual imediato e a obra como um todo", fornece, por meio das estratégias da própria obra em questão, os elementos necessários para que a ironia possa acontecer. O título do livro antecipa, subliminarmente, julgamentos e críticas que serão, aos poucos, esmiuçadas no decorrer do enredo. A idéia antecipada pelo título, mas talvez não apreendida antes da leitura da obra, de que o Brasil é uma terra dos que imitam e repetem comportamentos sem refletir sobre eles, é desenvolvida por meio da composição dos personagens, tanto os degredados quanto os indígenas (veja de que maneira o cacique Piquerobi acata as sugestões de Cosme e, muitas vezes, toma-as como idéias suas) e por meio das relações de exploração que a Coroa e seus representantes mantinham com os indígenas e com os degredados que aqui estavam. Enfim: desenha-se, pelo enredo e por outros elementos da narrativa, o pior dos mundos, o Brasil, a Terra dos Papagaios.

3 O vocábulo é entendido, aqui, na acepção tomada por Linda Hutcheon em Teoria e política da ironia (2000). À página 205, da referida obra, a autora define contexto como "todo o conjunto de suposições de fundo contra as quais você interpreta uma elocução" (SMITH, 1989, p. 73, apud HUTCHEON, 2000, p. 205).

Apud Hutcheon, 2000.

Cf. Hutcheon, 2000, p. 207 
O terceiro contexto proposto por Linda Hutcheon (2000, p.207), o intertextual, é "composto por todas as outras informações relevantes que se relacionam com a interpretação da elocução em questão". Essa elocução, composta pelo título em latim e seu equivalente em português, aciona outros textos e com eles se relaciona de modo a permitir que o significado irônico surja dessa relação.

Observe-se o fragmento seguinte, em que um dos autores da obra em questão, ao tratar de suas motivações para escrever, coloca publicamente suas opiniões político-ideológicas. Este enunciado não faz parte da obra, mas com ela se relaciona pela própria questão autoral. É essa contigüidade vista pelo leitor entre o posicionamento político do autor e a ambigüidade do adjunto adnominal "papagaios", que possibilita o aparecimento de um terceiro significado, irônico, em que o tal adjunto passa a ser lido, também, como crítica.

Como tive muitos professores humanistas, prendeu-se em mim essa idéia hoje tida como ridícula de que "devemos lutar por um mundo melhor", hoje trocada por "devemos maximizar os lucros". Acho que escrevendo, posso, de alguma forma, influenciar as pessoas. Posso fazê-las rir dos maus costumes e dos maus personagens, posso fazêlas perceber um vício e exaltar uma atitude, posso falar bem da honestidade e mal de Maluf e Pitta, posso falar bem da coerência e mal da compra de votos pela reeleição, posso falar bem da coragem e mal da aliança
com o PFL ${ }^{6}$.

O intertexto acima exposto contribui para a leitura do título como enunciado irônico. Além dele, outros intertextos cumprem esse papel. Por exemplo, parece ser quase de domínio público que a assertiva irônica. Observe-se o seguinte fragmento, publicado há dois anos, crítica um jornal de grande circulação, em que o autor acusa a nação des, em envolta na discussão repetida de temas, também repetidos:

É enfim, a repetição dos mesmos temas, como se fôssemos uma nação de psitacídeos ... Se tudo continuar do mesmo jeito, fica a sugestão de, na próxima reforma da "Constituição Cidadã", adotarmos o nome original e ${ }^{6}$ TORERO. Algumas razões nobres e outras plebéias. Home page:
http://www.redaçãonet.com.br. 
mais adequado para o Brasil: Terra dos Papagaios (AZEVEDO, 2001).

\section{Entre textos e contextos, o lugar do leitor}

Dessa breve discussão a respeito da questão dos contextos da ironia, advém obrigatoriamente outra: a da interação entre ironista, interpretador e contexto.

Abundam reflexões em que tal interação é tratada em termos de competência, ou seja, a ironia, para acontecer, deve, de acordo com tais reflexões, ser adequadamente interpretada pelo leitor, visto como um decodificador. A ironia, então, criaria comunidades de interpretadores, uma espécie de confraria intelectualmente privilegiada que, do topo de sua competência, escarneceria dos "outros", os interpretativamente incompetentes.

Talvez um questionamento possa nos ajudar a refletir sobre essas colocações: a decodificação de um enunciado irônico pressupõe que o leitor seja capaz de decodificar qualquer enunciado irônico?

De acordo com Linda Hutcheon (2000, p.46), o que está em jogo no processo de apreensão de uma ironia é o "compartilhamento de suposições em muitos níveis". Nesse sentido, é lícito dizer que a ironia acontece porque há crenças e valores comunitários preexistentes, compartilhados por aqueles que lêem um significado irônico. Nas palavras da autora (p.37):

Não é que a ironia cria comunidades ou grupos fechados; em vez disso eu quero argumentar que a ironia acontece porque o que poderia ser chamado de "comunidades discursivas", já existe e fornece o contexto tanto para o emprego quanto para a atribuição da ironia. Todos pertencemos simultaneamente a muitas dessas comunidades de discurso, e cada uma delas tem suas próprias convenções restritivas (HAGEN, 1992, p. 155). mas também capacitadoras.

Beth Brait (1996, p.105) não trata, em seu estudo sobre a ironia, da questão específica das comunidades discursivas mas, assim como Linda Hutcheon, assinala a importância da interação entre ironista e leitor: 
O conteúdo (do enunciado irônico), portanto, estará subjetivamente assinalado por valores atribuídos pelo enunciador, mas apresentados de forma a exigir a participação do enunciatário [....] Essa participação é que instaura a intersubjetividade pressupondo não apenas conhecimentos partilhados, mas também pontos de vista, valores pessoais ou cultural e socialmente comungados, ou, ainda, constitutivos de um imaginário coletivo.

Por meio dessa reflexão, pode-se chegar à resposta da provocação feita acima: um leitor pode ser expert na decodificação e até mesmo na produção de significados irônicos, mas pode, a qualquer momento, deixar "escapar" uma ironia. E mais, dois leitores diante de um mesmo enunciado irônico podem apreendê-lo de maneiras diversas.

Para observar de que maneira as comunidades de discurso possibilitam o surgimento da ironia em determinado enunciado, podemos nos valer das orelhas de Terra Papagalli. Nesse espaço intermediário, que já faz parte da obra na medida em que obedece a seus principais recursos estruturadores - paródia, ironia e jogo entre "real" e ficcional - mas que a ela se adianta por seu caráter de apresentação, fica patente de que maneira conhecimentos, conceitos e idéias preexistentes agregam uma determinada comunidade discursiva em torno de um significado irônico.

Para tal análise, contudo, tem-se que observar que as orelhas de Terra Papagalli dialogam ironicamente com dados externos à obra e, também, com a própria obra.

Num primeiro momento, então, temos ocorrências irônicas que são apreendidas facilmente por uma comunidade discursiva afeiti às letras, ou seja, uma comunidade que tem domínio de um determinado contexto intertextual. O diálogo paródico entre as orelhas do livro e um tipo textual, "orelhas", comporta uma ironia que será mais facilmente apreendida por aqueles que estão familiarizados com este tipo de discurso, que é laudatório sem assumir que o seja, que é marketing travestido em apreciação neutra. O texto das orelhas em Terra Papagalli expõe, pela ironia, essa postura não assumida dos discursos típicos das orelhas de livros.

Além disso, a referência rebaixadora a Pero Vaz de Caminha que, na verdade, tem por alvo a famosa Carta, também pressupõe um 
leitor que sabe que tal obra é nossa primeira e mais importante referência com relação aos primórdios da conquista do país. Imaginase que um leitor que não faça parte de uma comunidade discursiva que conheça a Carta de Caminha e seu valor tanto historiográfico quanto literário, não lerá o significado irônico que dá pistas sobre a obra cuja leitura iniciará: o leitor precisa não acreditar na desqualificação da Carta para não levar tão a sério assim os elogios à obra que tem em mãos. Por fim, a referência à Academia de Letras de Cananéia e a seu representante, Bartolomeu Bisagudo, é o derradeiro marcador irônico que exige uma leitura não ao pé da letra, mas que pressupõe múltiplos significados.

As orelhas da obra cumprem a função de qualquer orelha: orientar o leitor a respeito do que esperar da leitura que iniciará. Mas o faz de forma arrevesada. Por meio das referências irônicas acima discutidas, o texto em questão dá pistas ao leitor para que entenda a apresentação que se faz da obra como uma ocorrência irônica que requer, então, uma leitura diferenciada das seguintes passagens:

Antes, que se escolhessem obras como esta, leitor, que ora folheias, semeada de ensinamentos úteis, para melhor proveito e instrução de quem se aventura pela Terra dos Papagaios, hoje Brasil.

Pôde assim entremear a narrativa de suas aventuras em meio aos bárbaros gentis e não menos perigosos compatriotas com máximas de profunda utilidade para quem queira aqui habitar, comerciar e mesmo, se aprouver ao senhor, vencer na vida ${ }^{7}$.

É necessário sublinhar que não se pretende do leitor uma simples leitura antifrástica. Não é negando a utilidade dos ensinamentos contidos na obra que se chega ao significado irônico. Espera-se do leitor que ele apreenda que, "as máximas de profunda utilidade" semeadas pela obra não têm, na verdade, o caráter pragmático de orientação propagado pelas orelhas, mas que representam pontos para reflexão acerca da natureza deste país.

Se anteriormente aventamos a possibilidade de haver leitores que não partilham o contexto intertextual que possibilita a

Ambos os fragmentos pertencem às orelhas da primeira edição da obra, de 1997. A segunda edição, publicada em 2000, por outra editora, teve alterações no texto das orelhas e no layout da capa. 
interpretação das passagens acima transcritas como irônicas, é necessário acrescentar que nem por isso tais leitores teriam a sua leitura das orelhas totalmente comprometida. Se o leitor prosseguir com a leitura da obra, observará pouco a pouco que ela desmente suas orelhas que passariam, então, a ser lidas como irônicas, graças ao compartilhamento do contexto textual. A obra, seu enredo e sua estrutura, consiste, então, no contexto textual que auxilia o leitor na apreensão das orelhas como enunciados irônicos.

Todas as reflexões acima, a respeito dos contextos que permitem o funcionamento ${ }^{8}$ da ironia e a respeito da interação entre ironista, interpretador e contexto podem extrapolar o nível dos paratextos - título, orelhas - e ser aplicadas à totalidade da obra.

\section{Os textos do passado e o passado nos textos: a revisão irônica da
formação de um povo}

Linda Hutcheon (2000) não prevê em sua discussão, mas acreditamos ser proveitosa, para a leitura de Terra Papagalli, a divisão do contexto circunstancial em pelo menos dois subcontextos: o da escritura da obra e o das suas leituras ${ }^{9}$.

A primeira edição de Terra Papagalli, publicada em 1997, antecedeu muitas das discussões a respeito dos quinhentos anos do "descobrimento" do Brasil e do início do processo de colonização. Os diálogos irônicos, estabelecidos entre essa ficção e dados de nosso passado histórico, podem ser apreendidos nesse contexto de publicação. Estão presentes, em suspensão, quando da leitura de Terra Papagalli, clichês a respeito do perfil intelectual e moral de nossos exploratórias de nossa colonização, características absolutamente sido colonizados por outro povo europeu.

8 Por "funcionamento" entendemos, aqui, a formulação e a intelecção do enunciado irônico, ressaltando a idéia de que a existência de uma fómula irônica só existe, em última instância, se ela for entendida como tal (cf.
HUTCHEON, 2000).

O termo "leitura" é aqui empregado no plural porque acreditamos que ou, ainda, uma sobreposição de contextos ciro contexto circunstancial, vez, faz a ironia funcionar de maneiras diferentes. 
Contudo, esses diálogos são reafirmados ou, ainda, recriados numa leitura mais recente, levada a cabo depois das comemorações dos quinhentos anos, depois de todas as discussões que sobre esse assunto versaram, principalmente, no ano de 2000.

As circunstâncias que hoje cercam a leitura da obra são diferentes daquelas de quando a obra foi publicada pela primeira vez ou, ainda, escrita.

Não é possível ler Terra Papagalli hoje, sem ter em mente a situação dos povos indígenas, denunciada na época das comemorações dos quinhentos anos; o próprio evento comemorativo que "barrou" a participação popular e indígena; os protestos dos povos indígenas que recusaram o pedido de perdão da Igreja Católica, pela indiferença com que encarou a dizimação dos seus antepassados; a viagem fracassada da réplica da caravela de Pedro Álvares Cabral.

A apreensão de todos esses elementos que compõem 0 contexto circunstancial proporciona, também, uma facilitação da intelecção do contexto intertextual. A obra em questão dialoga paródica e ironicamente com textos que estiveram em voga nos últimos tempos. A Carta de Caminha, bem como outros textos a respeito do primeiro momento da colonização, foi retomada pelas escolas como texto de apoio de concursos literários, dentre eles o promovido pela multinacional Nestlé, além de se tornar peça de marketing dos Correios. Enfim, a própria história do Brasil foi rediscutida, abrindo espaço até mesmo para uma revisão do termo "descobrimento".

Como já foi mencionado, o funcionamento da ironia requer do leitor uma interação com os contextos que a envolvem e possibilitam a sua apreensão. Nesse sentido, a popularização de textos como a Carta e de discussões a respeito do descobrimento garantiram, de certa forma, que a sua recuperação paródica na obra fosse vista como irônica pelo leitor.

Outros textos, além dos de tradição e relevância histórica, compõem o contexto intertextual da ironia na obra em questão. Dois deles fazem parte da tradição ibérica e chegaram até nós por intermédio da influência portuguesa. São eles o bestiário e a novela de cavalaria. 
Temos uma obra de fundo satírico que faz uma releitura de parte da História do Brasil, além de estabelecer relações entre o passado e o presente por meio da dissimulação. Em poucas palavias descrevemos uma parte do contexto textual - há outras coisas relevantes, como a maneira como isso é elaborado na estratégia narrativa. Mas é a interação desse contexto com outros intertextos que faz a ironia funcionar. O leitor que se depara com um bestiário e um enredo típico de novelas de cavalaria inseridos numa obra contemporânea e satírica percebe uma espécie de sinal, que estudiosos costumam chamar de marcadores ${ }^{10}$.

Obviamente, partimos da pressuposição de que o leitor que faz a ironia funcionar, aqui, faz parte de uma comunidade discursiva que possui conhecimentos a respeito das duas tipologias textuais anteriormente citadas. De acordo com Muecke (1995, p.54):

Se entre o público de um ironista existem aqueles que não se dispõem a entender, então o que temos em relação a eles é um embuste ou um equívoco, não uma ironia, embora sua não compreensão possa muito bem acentuar o prazer da ironia para o público verdadeiro.

Há que se fazer uma ressalva a respeito desta reflexão do crítico. A interpretação da ironia parece estar relacionada muito mais com o compartilhamento de contextos, que pressupõe uma sintonia de conhecimento, pontos de vista e opiniões, do que com a disposição do leitor em apreendê-la - acreditamos que, exceto em casos de cinismo, é raro alguém não se dispor a entender a ironia ou optar pela sua não-
compreensão.

No entanto, é lícito crer, assim como faz o crítico, que o enunciado irônico só existe se alguém entendê-lo como tal e, caso este entendimento não ocorra, o que há é uma ambigüidade ou, ainda, nas palavras do estudioso, um "embuste". Há que se ressaltar a reiterada

10 De acordo com Linda Hutcheon (2000), o marcador irônico é "algo que sugere um enquadramento e, assim, um contexto no qual a ironia pode acontecer" (p. 213). A autora insiste no fato de que a existência de um marcador ou o seu sucesso "dependerá sempre de uma comunidade discursiva para reconhecê-lo, em primeiro lugar, e, então, para ativar uma interpretação irônica num contexto particular compartilhado: nada é um sinal irônico em si e por si só" (p. 227). 
distinção entre ironia e mentira colocada pelos estudos críticos que dão suporte a este artigo:

Uma sequiência irônica [é visualizada] como a construção em que existe a presença de um significante recobrindo dois significados, como acontece na mentira, mas integrada, obrigatoriamente, por um índice, cuja função é sinalizar a ironia, diferenciando-a da mentira ... no caso da mentira, o enunciador desqualifica o enunciatário, enganando-o; no caso da ironia, o enunciador qualifica o enunciatário como capaz de perceber o índice e participar da construção da significação irônica (BRAIT, 1996, p.49-50).

A intenção é uma das poucas maneiras que temos de distinguir, mentira de ironia. A diferença está na intenção da mentira de enganar (LEVIN, 1988, p.127), de segurar informação e na intenção temporária ou restrita da ironia de dissimular (com o propósito de avaliar) (HUTCHEON, 2000, p.172).

Usualmente não se pretende que as mentiras sejam interpretadas ou decodificadas como mentiras; ao contrário, as ironias são realmente apenas ironias quando alguém as faz acontecer (HUTCHEON, idem, p.101).

Nos logros existe uma aparência que é mostrada e uma realidade que é sonegada, mas na ironia, o significado real deve ser inferido ou do que diz o ironista ou do contexto em que o diz; é "sonegado apenas no fraco sentido de que ele não está explícito ou não pretende ser imediatamente apreensível (MUECKE, 1995, p. 54).

Deparar com textos da tradição literária portuguesa em uma obra cujo alvo de derrisão é, muitas vezes, o colonizador português poderia causar estranhamento se o aproveitamento de tais textos não fosse paródico. Se considerarmos, de acordo com Beth Brait (1996, p.107), que a paródia é uma das formas de relação entre discursos e também de exposição do "já-dito", podemos admitir que esse processo, ao recuperar a estrutura do bestiário e os clichês narrativos das novelas de cavalaria, estabelece uma relação irônica com os textos de fundo - neste caso difusos - da paródia e com o momento histórico em que eles eram produzidos e lidos. E mais, ao legar a autoria destes textos ao personagem Cosme, lançam-se farpas ao que ele representa: 
o colonizador português. O personagem Cosme Fernandes, autor fictício da também fictícia carta-biográfica que o leitor tem em mãos, coloca em pauta, como já se disse, clichês a respeito do colonizador.

Observem-se as passagens abaixo, em que a ingenuidade do personagem parece reiterar aquelas considerações de ampla circulação a respeito da inteligência dos portugueses. No primeiro fragmento, o personagem Cosme Fernandes relata o seu encontro com Lopo de Pina, condenado ao degredo por ter assassinado o irmão por causa da herança do pai. É interessante observarmos, aqui, a credulidade de Cosme, ao confiar na versão do acontecido, exposta por Lopo de Pina. O segundo fragmento traz, mais uma vez, a ingenuidade de Cosme diante do mesmo personagem. Desta vez, ambos já são inimigos pelo fato de Lopo de Pina ter caído nas graças de Pero Capico, capitão deixado em terra por Martim Afonso para tratar da distribuição de glebas entre os degredados. O fragmento narra o primeiro reencontro dos personagens depois que Lopo de Pina, na partilha das terras, ficou com o Porto construído por Cosme, enquanto ele foi mandado, com
sua família, para um lugar inóspito.

Este (o irmão de Lopo de Pina) se chamava Nuno e. no testamento deixado pelo pai, ficara com as melhores terras da família ... (Lopo de Pina) Contou que estavam a caçar javalis e, ao dar um disparo, por obra do vento ou do demônio, a seta desviou-se de maneira tal que, em vez de acertar o pescoço do animal, entrou pela orelha esquerda de Nuno. Falou-me isso com lágrimas nos
olhos e eu, comovido, abracei-o.

E então ele disse: "E mais que tudo, meu querido Bacharel, lembras-te que fui eu quem te batizou com
esse apelido?" Quando ouvi isso, veio-me à mente aquele dia a bordo da nau, quando Lopo de Pina fazia momices e todos ríamos como se fôssemos homens felizes e não pobres desatinado. Ele também rompi num pranto copioso e soluços:

"Vamos esquecer de todas essas disputas. Queres o porto de São Vicente? É teu. Vamos ao capitão-mor e assinemos os papéis. Não quero dinheiro, quero tua 
Ouvindo tamanha demonstração de boa-fé. chorei ainda mais, pois bateu-me um grande arrependimento por tê-lo julgado mal, sentindo-me o mais cruel e injusto dos homens.

E assim passamos a noite a beber e relembrar os velhos tempos. ...

Na manhã seguinte, antes do nascer do sol, zarpou Diogo Garcia. ... Fui então acordar Lopo de Pina para andarmos na praia, mas não o encontrei. Depois de muito procurar vi que não somente ele havia desaparecido, mas também um bote e aquele baú, dito Divina Providência, onde guardava o ouro e as moedas com que nos haviam pagado os navegadores naqueles anos todos (TORERO \& PIMENTA, 1997, p. 22.

É necessário, contudo, observar que esta primeira interpretação a respeito da ingenuidade de Cosme - que desmascara o colonizador português por meio do clichê da inteligência insuficiente - pode ser completada por uma outra. Caso não nos esqueçamos do fato de que a ingenuidade do personagem, expressa nestes dois fragmentos, contrasta com a sua esperteza em tantos outros, podemos sugerir que estamos diante de um caso de dissimulação irônica. De acordo com Muecke (1995, p.58), "O ironista, em seu papel de ingênuo, propõe um texto, mas de tal maneira ou em tal contexto que estimulará o leitor a rejeitar o seu significado literal expresso, em favor de um significado 'transliteral' não expresso de significação contrastante".

Ao lermos o primeiro fragmento, que se localiza no início da obra, ainda não temos conhecimento aprofundado do caráter de Lopo de Pina. No entanto, a apresentação do personagem e de seu crime, feita por Cosme, de modo a enfatizar a versão do próprio criminoso de que tudo não passara de um acidente, provoca uma certa desconfiança no leitor. A ingenuidade de Cosme Fernandes torna-se, então, um sinal, uma advertência para que o leitor não creia na honestidade de Lopo de Pina.

No segundo fragmento é ainda mais marcante a credulidade do personagem principal, visto que, a essa altura da narrativa, Lopo de Pina já havia colocado em prática sua máxima favorita - "quem não come é comido" - apoderando-se do porto construído por Cosme. 
A ingenuidade, nesses fragmentos, caracteriza-se como marca de ironia. É por meio da ingenuidade explícita e exagerada do personagem principal que o leitor percorre o caminho inverso e opta pela desconfiança em relação a Lopo de Pina. Isso ocorre porque a ingenuidade ativa o clichê, compartilhado entre ironista e leitor, da parca inteligência dos portugueses.

Por outro lado, os mesmos exemplos, que acima foram tomados a fim de demonstrar a ingenuidade de Cosme Fernandes e a ativação de um estereótipo popular, podem ser utilizados para demonstrar uma certa esperteza desonesta do seu antagonista Lopo de Pina. Tal personagem que, desde a viagem rumo ao Brasil dá mostras de sua desonestidade, é curiosamente caracterizado por Cosme como "satírico". A composição deste personagem também parece apontar ironicamente para um certo estereótipo da malandragem, no mau sentido. Lopo de Pina coloca em evidência um clichê popular a respeito do brasileiro: o de ser esperto, tentar levar vantagem a
qualquer meio, de preferência, sem esforço.

O expediente de expor a ingenuidade, ou mesmo a credulidade exagerada de certo personagem para sinalizar ao leitor que deve entender determinada passagem como irônica, é utilizado na composição da carta que Mbiracê escreve a seu pai, de Lisboa. A personagem, filha mais velha de Cosme Fernandes com a índia Terebê, casou-se com Francisco Chaves e, com ele, foi morar em Portugal. De lá, escreve esta carta - da qual são reproduzidos, abaixo, alguns fragmentos - para registrar as suas impressões da Europa:

\section{Meu amado pai}

Hoje é quinze de agosto e meu marido está em frente de mim escrevendo também uma carta para o senhor porque há novidades e ele as vai contar. Vou achando tudo aqui muito interessante mas não acerto com esse negócio de comer com garfos. Quando chegamos ri muito de ver tanta gente de cara barbada, mas o que mais me espantou foram homens e mulheres que são cobertos de uma tintura preta e estes servem os que têm a cara pálida e todos andam sempre com muita roupa mesmo quando há calor e isso me parece muito muito tolo. Nunca disseste que os homens daqui têm apenas uma esposa e desconfio que fazem assim porque são fracos e não conseguiriam agradar a duas mulheres ... Animais também engraçados 
são uns que chamam touros que são grandes como duas antas juntas e têm cornos em forma de meia-lua e às vezes os naturais os soltam em caminhos estreitos e põem-se a correr na frente deles e isso me parece pouco inteligente pois se têm medo deles não sei porque os soltam. Há umas ocas muito muito grandes e mais fortes que as nossas e há outras pequenas onde moram muitos, e quando Tupã manda chuva de trovões elas se desmancham ... O cheiro deste lugar é tão ruim quanto o do naritataca e há umas mulheres que ficam num lugar chamado Ribeira e recebem moedas para se deitarem com os homens e isso deve ser muito bom porque variam o marido e ainda ganham por isso. Perguntei a Francisco se poderia ficar com elas e ele gritou-me e disse que nunca mais the pedisse uma coisa dessas mas não entendi por quê (TORERO \& PIMENTA, 1997, p. 157-8).

Nesse fragmento, a estratégia utilizada é expor, inicialmente, a inadaptabilidade de Mbiracê na sociedade civilizada, da qual agora ela faz parte. A sua inabilidade em lidar com os talheres, a sua ignorância acerca da raça negra e da escravidão e mesmo seu inconformismo com o fato de todos permanecerem vestidos, mesmo com o calor escaldante, provocam no leitor uma primeira reação de riso. Parecenos que o riso, aqui, não é o do escarnecimento, da sátira: a figura da índia é simpática e o riso que sua inadaptabilidade provoca é um riso de simpatia, quase de cumplicidade, ao qual Propp (1992) denominou "riso bom". O sentimento de simpatia é reforçado, ainda, por este trecho da carta de Francisco Chaves, apresentada logo após a carta da india:

\section{Senhor meu sogro,}

Chegamos na Páscoa, e com as moedas que trouxe logo pude abrir uma sapataria. Para evitar problemas, disse a todos que me chamava Pascoal Soares e que Mbiracê é uma escrava que trouxe das Índias (Idem, p.158).

No entanto, conforme a leitura da carta avança, o foco de atenção é desviado: da inadaptabilidade de Mbiracê para os desatinos da sociedade civilizada. A incompreensão e a surpresa de Mbiracê diante dos costumes e convenções da civilização transforma-os, aos olhos do leitor, em desatinos, em ilogismos. Neste sentido, é lícito 
conferir à índia, nesta passagem, o papel de persona satírica, com o respaldo da seguinte reflexão de Mathew Hodgart (1969, p.124):

Este último procedimiento (adotar un porta-voz) es difícil de sostener y se há demostrado que habitualmente es más efectivo inventar un personaje distinto del autor, bien por su edad o por su condición social. Puede ser este um niño o un salvaje que no comprenden las normas de la sociedad adulta y civilizada, y que se niegam a admitir los valores simbólicos que dicha sociedad concede a objetos o acciones aparentemente triviales; de este modo lo absurdo de las instituciones sociales queda patente cuando se reducen a términos infantiles o primitivos.

Se a persona satírica é um recurso amplamente utilizado pela sátira para desmascarar convenções e costumes vazios de sentido ou, ainda, absurdos e carentes de lógica, neste fragmento a sua adoção ainda faz a ironia funcionar. É improvável que um leitor, que partilhe com o ironista os contextos circunstancial, textual e intertextual, não leia a carta de Mbiracê como um enunciado irônico.

Esses leitores estão adaptados a olhar para a sociedade indígena com a curiosidade que é provocada por tudo o que é pitoresco e estranho, no sentido de diferente, e por meio desse olhar tiram as suas conclusões antropológicas, científicas e, mesmo, preconceituosas. E, se não olham desta forma, estão acostumados a ler textos em que autores e cronistas assim o fazem.

O que temos, então, nesta carta de Mbiracê, é uma inversão: é o índio que vê como pitoresca a sociedade civilizada e, ainda, como estranhos e dignos de espanto os seus hábitos. É digno de nota que a índia se refira aos portugueses como "naturais", expressão utilizada sempre, na obra, pelos personagens portugueses para se referir aos
índios.

Em muitos momentos desta presente análise usamos expressões tais como "a ironia funciona", "a ironia é ativada" e "a ironia acontece", para ressaltar o fato de que, mais do que estar presente num texto como instrumento retórico, estático, que o leitor deve reconhecer e interpretar, a ironia é um "processo comunicativo" (HUTCHEON, 2000, p.90) que envolve questões como ativação de 
contextos - como já vimos, textual, circunstancial e intertextual - e sua interação com o ironista e com o leitor.

É por meio dessa opção teórica que podemos chegar às três características semânticas do significado irônico, que é relacional, inclusivo e diferencia (ibidem). Entender o significado irônico como relacional é aceitar o fato de que a leitura da ironia envolve não a apreensão dos significados subliminares em detrimento dos significados expressos mas a interpretação de um terceiro significado, resultante da interação e/ou do confronto entre aqueles dois. Além disso, pressupõe também o fato de que esta apreensão depende e é modificada pelas pessoas envolvidas nesse particular processo comunicativo (ironista e interpretador) e pelos contextos dos quais elas fazem parte e com os quais interagem.

A característica relacional do significado irônico é a que nos permite interpretá-lo também como inclusivo e diferencial. Isso porque, se a ironia surge do confronto entre o dito e o não dito, podemos pressupor que ambos são essenciais ao seu funcionamento, uma vez que adquirem significação apenas quando confrontados e que desse confronto é que surge a ironia propriamente dita. É necessário sublinhar o fato de que o aspecto inclusivo da ironia vai de encontro aos estudos que a vêem como um processo exclusivo, em que o leitor opta pelo não-dito em detrimento do dito. Para estas teorias o significado irônico é aquele que é sonegado pelo texto.

Quanto ao fato de a ironia possuir um caráter diferencial, este pode ser explicado ao confrontá-la com a metáfora. Os significados que entram no jogo da enunciação para resultarem num terceiro, este sim, irônico, apesar de não serem excludentes, são diferentes. Se na metáfora há uma extensão de um significado no outro - extensão permitida apenas porque há similaridade entre eles -, na ironia há um confronto entre significados diferentes, do qual emerge um terceiro, este sim, chamado de irônico. Nas palavras de Linda Hutcheon (2000, p.177), "a metáfora se apóia na percepção de similaridade na diferença, enquanto a ironia necessita de discriminação de diferença entre o dito e o não-dito".

Já tivemos a oportunidade de observar um primeiro aspecto da característica relacional da ironia quando tratamos dos contextos. Naquele momento, vimos de que maneira o enunciado irônico é compreendido de determinada maneira - ou mesmo não é 
compreendido - de acordo com o compartilhamento que leitor e ironista têm dos contextos circunstancial, textual e intertextual; compartilhamento este que determinará o enquadramento da ironia .

Podemos retomar o nosso corpus e verificar de que maneira, em Terra Papagalli, as características do enunciado irônico, acima descritas, interagem.

A ironia, na obra em questão, pressupõe a interação e o confronto de diversos significados. Podemos tomar como exemplo os pares passado e presente; indigena e colonizador; barbárie e civilização. Se nos ativéssemos a uma análise que priorizasse o nãodito, por conferir a ele o papel de significado irônico, chegaríamos à conclusão de que os primeiros elementos de cada par corresponderiam ao que é, na obra, declarado, mas que, de acordo com a intenção do ironista, deveria ser rechaçado, e que os elementos que os seguem corresponderiam ao que se espera que o leitor apreenda, apesar de sonegado pelo texto: o significado irônico.

Esta primeira opção de análise - que, adiantamos, será revista adiante - pode até ser aplicada a alguns fragmentos do texto:

Primeiro mandamento para bem viver na Terra dos Papagaios

$\mathrm{Na}$ Terra dos Papagaios é preciso saber dar presentes com generosidade e sem parcimônia, porque os gentios que lá vivem encantam-se com qualquer coisa, trocando sua amizade por um guizo e sua alma por umas contas (TORERO E PIMENTA, 1997, p.61).

É necessário ressaltar que esse primeiro "mandamento" é o primeiro de uma série de dez - o que nos remete, imediatamente, ao decálogo de Moisés - que o personagem Cosme Fernandes entremeia à narrativa de suas aventuras, para orientar o seu interlocutor, Conde de Ourique, a respeito dos costumes da terra.

Esse primeiro excerto, quando lido inserido no contexto textual que inclui a narrativa que o antecedeu, a narrativa que o segue e, sobretudo, os outros nove mandamentos, oferece ao leitor significados que se relacionam, que se chocam: afinal de contas, falase realmente da Terra dos Papagaios, do Brasil de 1500? Ou o costume que ali se descreve pode ser aplicado aos dias de hoje, ao Brasil de hoje? A dúvida aumenta ao retomarmos uma frase da orelha 
da obra, em que o resenhista, Bartolomeu Bisagudo declara: “...para melhor instrução de quem se aventura pela Terra dos Papagaios, hoje Brasil". A utilização do adjunto adverbial anteriormente sublinhado sugere a relação entre passado e presente.

$\mathrm{O}$ fragmento seguinte exemplifica de que maneira indígena e colonizador são colocados em confronto para, mais uma vez, sugerir ao leitor um significado não expresso:

Não vos direi como fiquei abatido naqueles dias. Não falava, não dormia, não comia e só tinha ânimo de ficar na rede olhando as formigas que passavam. Quando expliquei a Terebê que teríamos que partir, ela ficou triste e aborrecida, pois sendo rústica, não conseguia entender como vinha um homem de longe e nos obrigava a sair de nossas terras, abandonar os parentes e ir morar num lugar vizinho dos inimigos (TORERO $\mathrm{E}$ PIMENTA, 1997, p.139).

Nesse fragmento, a crítica à rusticidade da índia Terebê - a primeira das "esposas" de Cosme - coloca em funcionamento um outro significado, contrastante e não expresso: o de que, na verdade, é incompreensível a submissão entre os homens, sobretudo pelo fato de que a suposta superioridade não advém de mérito pessoal, mas da indicação de um terceiro.

A citação, que abaixo se apresenta, reitera o que dissemos até aqui, confrontando barbárie e civilização e, aparentemente, demonstrando que a barbárie indígena (sob o ponto de vista do colonizador) está muito próxima das barbáries cometidas pela sociedade dita civilizada.

Nesse momento, senhor, pensamos que eles (os prisioneiros mortos) seriam queimados em sacrifício, como nos rituais dos povos antigos. Mas, passado um tempo, Piquerobi foi até o moquém e arrancou o dedão do pé do prisioneiro. ... Só então percebemos que o fïm que davam aos inimigos era comê-los (p.86).

No fragmento, aproxima-se um "ritual civilizado" de um ritual indígena; quando o narrador coloca o primeiro em termos de aceitação e o segundo em termos de reprovação, o que se tem, na verdade. é uma crítica à presunção do branco, que acredita que seu ritual é legítimo em face do ritual indígena, este sim, aterrador. 
Todos os exemplos acima servem para comprovar a teoria, talvez a mais propagada, de que o significado irônico é aquele que não está expresso e que pode ser inferido por meio da leitura do texto. No entanto, queremos argumentar que a ironia nasce do atrito de dois significados diferentes, o expresso e o subentendido, sendo, portanto, relacional, inclusiva e diferencial. Em outras palavras, é da relação entre o dito e o não-dito que o leitor apreende um terceiro significado, este, irônico.

Nesse sentido, nos três exemplos dados acima, nos quais dois significados diferentes se relacionam e se confrontam, não lemos a ironia descartando o primeiro elemento dos pares em proveito dos outros, mas a lemos como resultante da interação entre os dois.

E se aceitássemos a primeira opção de análise - e também a mais difundida entre os críticos - seria simples entender o que as arestas da ironia ${ }^{11}$ atingem, ou, em outras palavras, para o que se volta a atitude avaliadora e julgadora que a caracteriza como um modo de discurso que pressupõe envolvimento emocional. Teríamos, então, ironias cujas arestas atingiriam o momento histórico presente, a suposta superioridade do colonizador diante dos índios e a também suposta civilidade da sociedade européia.

No entanto, acreditamos que a ironia, no caso de Terra Papagalli, tem por alvo principal o processo de formação de uma nação, aí incluídos os seus hábitos, os seus costumes e a sua própria imagem como povo. A apreensão simultânea de significados relativos ao passado historiográfico e ao presente da leitura engendra ainda um outro significado, o de avaliação crítica, julgadora, do processo de
formação do país.

É nesse sentido que elementos do discurso historiográfico são retomados na obra. Ao mesmo tempo que eles contribuem para que leitor e ironista compartilhem dos mesmos contextos da ironia, vejamna sob um mesmo enquadramento, eles também são tomados como
alvo e reavaliados sob a égide irônica.

Em suma, acreditamos que não apenas o passado e o presente são avaliados por meio da expressão irônica, mas também - e, talvez, principalmente - o que perdura de um, no outro e que, podemos arriscar, continuará perdurando daqui em diante, no futuro. São os

1 Cf. HUTCHEON, 2000, passim. 
elementos que se estendem no presente sob a forma de vícios, tais como a corrupção das instituições e dos homens, a credulidade que favorece tanto os charlatães quanto os arrivistas, a infidelidade às ideologias etc. (os mandamentos oferecem outros sete exemplos de vícios que perduram até hoje, no Brasil), que foram escolhidos como características de nossa formação enquanto povo, enquanto nação, e que são atacados pela sátira.

A sátira, em sua atitude crítica e, sobretudo, reformadora, serve-se da paródia que retoma, por meio de textos representativos, o passado. A ironia aponta que a leitura destes textos e, por conseguinte, deste passado, depende da apreensão de múltiplos significados, elaborados e reelaborados de acordo com cada contexto, de acordo com diferentes enquadramentos. E é desta forma que se tem a revisão satírica não só do passado ou do presente mas, principalmente, desse "entretempo" no qual nos formamos como nação.

A criação desse "entretempo", que assinala uma contaminação mútua entre passado e presente e o abandono da idéia de existência de uma progressão temporal que resultaria, forçosamente, em evolução, constitui um dos traços de pós-modernidade presentes em Terra Papagalli e cuja investigação extrapolaria os limites e objetivos deste artigo. 


\section{Referências bibliográficas}

ABREU, C. O descobrimento do Brasil. Rio de Janeiro: Civilização Brasileira, 1976.

AZEVEDO, J.C. A. Terra Pappagallorum. Folha de S. Paulo, São Paulo, 26 mar. 2001. Opinião. Caderno A, p. 3.

BRAIT, B. Ironia em perspectiva polifônica. Campinas: Edunicamp, 1996.

ECO, U. Seis passeios pelo bosque da ficção. São Paulo: Companhia das Letras, 1994.

FERREIRA, A. B. de H. Novo dicionário Aurélio da Língua Portuguesa. Rio de Janeiro: Nova Fronteira, 1986.

HODGART, M. La satira. Madrid: Guadarrama, 1969.

HUTCHEON, L. Teoria e política da ironia. Tradução Julio Jeha. Belo Horizonte: Ed. UFMG, 2000.

MUECKE, D. C. Ironia e o irônico. Tradução Geraldo G. de Souza. São Paulo: Perspectiva, 1995. (Coleção Debates).

PROPP, V. Comicidade e riso. Tradução Aurora F. Bernardini e Homero F. de Andrade. São Paulo: Ática, 1992.

TORERO, J. R. \& PIMENTA, M. A. Terra Papagalli. São Paulo: Companhia das Letras, 1997.

TORERO, J. R. Algumas razões nobres e outras plebéias (depoimento). Disponível em: http://www. redação. net. com.br. Acesso em 25 abr. 2001. 